\title{
Analytical Quantifiation, immunomodulatory and Sulfor- hodamine B assay studies on Albizia lebbeck Leaves Extracts
}

\author{
Gaurav Mahesh Doshi ${ }^{*}$, Manjushree kundalik Pawar ${ }^{2}$, Kajal Haribhai Chavda² \\ 'Department of Pharmacology, Vivekanand Education Society's College of Pharmacy, Chembur (E), Mumbai-400074, INDIA. \\ ${ }^{2}$ Department of Quality Assurance, Vivekanand Education Society's College of Pharmacy, Chembur (E), Mumbai-400074, INDIA.
}

\begin{abstract}
Background: Albiza lebbeck leaves have been well known for its ethnopharmacological prospects. Objective: The present study aims three extracts (aqueous, methanolic and hydromethanolic) at two dose levels by oral administration by using immunomodulatory models and in vitro cell lines in correlation to analytical studies. Methods: The extracts were subjected to Haemagglutination Antibody Titre and DTH Delayed-Type Hypersensitivity reaction based on acute toxicity results. Chromatographic studies were undertaken comprising of Fourier Transform Infrared Spectroscopy and High performance Thin layer Chromatography and screened for in-vitro cell lines such as MCF-7 and HCT 15 by Sulforhodamine B Assay Method. Results: No response was shown at $100 \mathrm{mg} / \mathrm{kg}$. Significant immunomodulatory effect was noticed at $200 \mathrm{mg} / \mathrm{kg}$ with Haemagglutination Antibody Titre $(554.66 \pm 102.78,597.33 \pm 85.35,426.66 \pm 53.98)$ and DTH DelayedType Hypersensitivity reaction $(0.225 \pm 0.01,0.21 \pm 0.01,0.23 \pm 0.01)$ which showed decrease in paw volume (after $48 \mathrm{~h}$ ) in case of Sheep Red Blood Cells, $\left(0.5 \times 10^{9}\right)$ used as antigens. Total flavonoids content in the extracts were revealed by methods described by Singleton and Quettier. Flavonols such as rutin and quercetin were detected by Fourier Transform Infrared
\end{abstract}

Spectroscopy based on determination of the functional groups and High Performance Thin layer Chromatography showed well resolved spots. The extracts were screened on in-vitro cell lines (MCF 7 and HCT 15) by using Sulforhodamine B Assay method were unsatisfactory results were obtained at final concentrations of $10 \mu \mathrm{g} / \mathrm{ml}, 20 \mu \mathrm{g} / \mathrm{ml}, 40 \mu \mathrm{g} / \mathrm{ml}, 80 \mu \mathrm{g} / \mathrm{ml}$. Conclusion: Thus, present paper suggests that extracts has served as a promising immunomodulator for immune system disorders.

Key words: Delayed-Type Hypersensitivity response, Haemagglutination Antibody Titre, Fourier Transform Infrared Spectroscopy, High performance Thin layer Chromatography, Rutin, Quercetin, MCF-7.

Corresponding author: Dr. Gaurav Mahesh Doshi, Assistant Professor, Department of Pharmacology, Vivekanand Education Society's College of Pharmacy, Mumbai-400074, Maharashtra, INDIA.

Phone no: 9819771515

Email: gaurav.pharmacology@gmail.com

DOI : 10.5530/pj.2016.5.11

\section{INTRODUCTION}

Immune system is one of the most complex biological systems comprising of dense network of cells. The cells play important role in maintaining the immunity within the system by either performing process of phagocytosis against micro-organisms, fungi viruses etc or attacking the nonself-cells by release of natural killer cells.

Immunodeficiency diseases are the conditions where the defense mechanisms of the body are impaired, leading to repeated microbial infections of varying severity and occasionally enhanced susceptibility to malignancies. Deficiencies of defense mechanisms involve specific (humoral and cell) and non-specific immune (phagocytosis and complement) functions. ${ }^{2}$

Allopathic medicines used in treatment are found to pose life threatening side effects of growth retardation, osteopenia, hyperglycemia, nephropathy, hypertension, wound healing and increased chances of risk of infection..$^{3-5}$ Medicinal and local plants researches in the field of immunology have brought an immense breakthrough by influencing the system as well as playing their role as an immunoadjuvants, immunosuppressant and immunostimulants. ${ }^{6}$ India's cultural heritage system has put its roots in supporting Glycyrrhiza glabra, Uncaria tomentosa, Tinospora cordifolia, Allium asativum, Aloe vera, Angrographis paniculata, Asparagus racemosus, Azadirachta indica, Curcuma longa, Nycanthes arbortristis, Ocimmum sanctum, Panax ginseng, Pylanthus embilica, Withania somnifera, Hibiscus esculentum, Mangifera indica, Piper betel and Saraca indica with immunomodulatory perspectives etc.. ${ }^{2,7}$

Albizia lebbeck (AL, commonly known as Shirish) has been comprehensively recommended to remove toxins from the body. The plant is a deciduous woody tree, approx.12-21 $\mathrm{m}$ in height, having pale bark with glabrous young shoots. Its leaves are reported to be good in treatment for ophthalmic diseases, night blindness, syphilis, respiratory problems, ulcers and cold cough. Kwath (herbal tea) made from the bark is indicated for asthmatic patients as it helps to control the frequency and intensity of the dyspnea induced due to asthmatic. Literature has brought to our due consideration that the selected plant has been reported to possess antiasthmatic, antiseptic, antitubercular, antiepileptic, anti-dysenteric, antiinflammatory, anti-fertility and antidiarrheal activities. The bark has been well known for its immunomodulatory potential..$^{8-9}$

In current research studies, researchers have tried to evaluate AL plant leaves extracts (Aqueous, Methanolic and Hydromethanolic extracts) for their immunomodulatory potential, followed by screening then for specific cell lines like breast cancer (MCF-7) and colon cancer (HCT-15) supported with activity guided phytochemical quantification of flavanols phytoconstituents such as rutin and quercetin by estimating total flavanoids as well as studying the constituents by HPTLC and FTIR. The studies were carried out on aqueous, methanolic and hydromethanolic extracts. The studies has provided the researchers a crystal clear view in deciding which of the studied extract as good activity related to immune system as mentioned in graphical abstract (Figure 1).

\section{MATERIALS AND METHODS}

Collection, authentication, extraction and preliminary phytochemical screening of AL leaves

The leaves were collected from Gharaunda, India. It was authenticated at Agharkar Research Institute, Pune, India (voucher no.15-217). The leaves were shade dried, crushed and finely powdered passing through sieve no. 80 to remove the twigs and associated materials. The fine powder was subjected to different extraction procedures as depicted below. These 
extracts were stored at $8-15^{\circ} \mathrm{C}$ for analytical quantification, immunomodulatory and invitro cell lines studies.

\section{Methanolic extract of Albizia lebbeck (MEAL)}

The powder was macerated using methanol in extraction bottle (100 $\mathrm{g}$ in $500 \mathrm{ml}$ ) and was kept in dark place at room temperature for 7-10 days with occasional shaking. On the $8^{\text {th }}$ day, it was subjected to orbital shaking and dry form was obtained with the help of rotary evaporator.

\section{Hydromethanolic extract of Albizia lebbeck (HMAL)}

The powder was extracted with 70: 30 ratio of methanol and water (50 g in $500 \mathrm{ml}$ ) and subjected to soxhlet extraction at $55^{\circ} \mathrm{C}$ and dry form was obtained on rotary evaporator.

\section{Aqueous extract of Albizia lebbeck (AQAL)}

The powder was extracted with distilled water $(50 \mathrm{~g}$ in $500 \mathrm{ml})$ and heated on water bath at $95^{\circ} \mathrm{C}$. It was filtered by Whatman filter paper no. 1 and subjected to vacuum pressure in order to obtain dry form.

\section{Determination of powder characteristics of the extracts}

The extracts were subjected to total ash value, acid insoluble ash, water soluble ash, water soluble extractive, alcohol soluble extractive, total solid content and loss on drying as described by Khandelwal. ${ }^{10}$

\section{Preliminary phytochemical screenings of the extracts}

The extracts were subjected to preliminary phytochemical studies as described by C.K Kokate. ${ }^{11}$

\section{Total flavonoid estimation in the extracts}

The amount of total phenolics and flavonoids content in the MEAL, HMAL and AQAL extracts were measured using Singleton and Quettier methods. ${ }^{12,13}$ using rutin as a standard. Results were expressed as rutin equivalents in mg per $\mathrm{g}$ of $A$. lebbek leaves.

\section{Analytical studies}

\section{Thin Layer Chromatography (TLC)}

Identification of the rutin and quercetin by using were methanol: glacial acetic acid: formic acid: water (3:0.9:0.9:0.5) and toluene: ethyl acetate: formic acid (5:4:0.2) respectively. The standard and extract samples were dissolved in the methanol $(10 \mathrm{mg}$ in $1 \mathrm{ml})$ and were filtered through Whatman filter paper no.1 before spotting on the plate. The TLC plate was exposed to ammonia and visualized under UV lamp.

\section{High Performance Thin Layer Chromatography (HPTLC)}

The studies were performed at the Anchrom Test Lab Pvt. Ltd., Mumbai. The quantification was carried out by the application of the spots on HPTLC plate impregnated with silica gel (plate size of $20.0 \times 10.0 \mathrm{~cm}$ ). The extracts $(200 \mathrm{mg}$ ) and standards $(5 \mathrm{mg}$ ) were dissolved in $5 \mathrm{ml}$ of methanol. Scanning of developed plates was carried out under UV visible wavelength at $254 \mathrm{~nm}$ but well resolved spots were obtained only after derivatization at $540 \mathrm{~nm}$. The details of the instrument used in studies was CAMAG LINOMAT 5 with 5 application parameter, inert gas as spray gas, methanol as sample solvent with dosage speed $150 \mathrm{nl} / \mathrm{s}$ and predosage volume $0.2 \mu \mathrm{l}$. Syringe size was $100 \mu \mathrm{l}$ with 10 numbers of tracks, $8 \mathrm{~mm}$ application position and $8 \mathrm{~mm}$ band length. The calibration parameters used was calibration mode multilevel, with $\mathrm{CV}$ statistics mode and the evaluation mode was based on peak areas. The results were calculated based on the formula.

$$
\begin{aligned}
& \text { Area of sample } \times \text { standard dilution } \times \\
& \% \text { of constituent }: \frac{\text { purity of standard } \times 100}{\text { Area of standard } \times \text { sample dilution }}
\end{aligned}
$$

\section{Fourier Transform Infrared (FTIR) spectroscopy}

The studies were performed at Vivekanand Education Society's College of Pharmacy, Chembur, Mumbai. The standards and extracts in powdered form were placed directly over the zinc-selenium crystals fitted into the die cavity of sample holder and spectrum was obtained in the range 500-4000 $\mathrm{cm}^{-1}$ using the software IR solutions and the results were interpreted. The instrument used in studies was on Shimadzu IR Affinity with scanning speed of $2 \mathrm{~mm} / \mathrm{sec}$.

\section{Animal studies \\ Standard drugs and chemicals}

Ashwagandha Churna was used as a standard herbal drug procured from local retailer supplier. Standard biomarkers (rutin and quercetin) were obtained from Sigma Aldrich Private Limited, Mumbai. All the chemicals used throughout the experimentation purpose were procured from local suppliers.

\section{Animal Studies}

The protocol for animal studies was approved by Vivekanand Education Society's College of Pharmacy, Mumbai, Maharashtra, India (VESCOP/ 05d/2015) and was in accordance with International Standards on Care and Use of Experimental Animals (CCAC, 1993). Albino Wistar rats of either sex obtained from Bharat Serums and Vaccines Ltd., Mumbai, each weighing between 120 - $150 \mathrm{~g}$ were used for this studies. All the rats were dosed according to body wt. using p.o. The nine groups were as follows:

Group I: Served as control ( $0.5 \%$ sodium CMC solution at $1 \mathrm{mg} / \mathrm{kg})$.

Group II: AQAL extract at $100 \mathrm{mg} / \mathrm{kg}$.

Group III: AQAL extract at $200 \mathrm{mg} / \mathrm{kg}$.

Group IV: HMAL extract at $100 \mathrm{mg} / \mathrm{kg}$.

Group V: HMAL extract at $200 \mathrm{mg} / \mathrm{kg}$.

Group VI: MEAL extract at $100 \mathrm{mg} / \mathrm{kg}$.

Group VII: MEAL extract at $200 \mathrm{mg} / \mathrm{kg}$.

Group VIII: Ashwagandha Churna at $100 \mathrm{mg} / \mathrm{kg}$.

Group IX: Ashwagandha Churna at $200 \mathrm{mg} / \mathrm{kg}$.

\section{Experimental conditions}

The animal experimentation area was air-conditioned maintaining light cycle of $12 \mathrm{~h}$ light and $12 \mathrm{~h}$ dark, temperature $22 \pm 1^{\circ} \mathrm{C}$ and relative humidity $65 \pm 10 \%$. They were housed in groups of 3 in rectangular cages made from plastic with paddy husk bedding and fed with standard pellet food. The animals were fasted for approximately $16 \mathrm{~h}$ before study with free access to water.

\section{Preparation of Antigen, standard and extracts}

Fresh blood was collected from sheep sacrificed in the local slaughter house. Sheep red blood cells (SRBCs) were washed three times in large volumes of pyrogen free $0.9 \%$ normal saline and adjusted to a concentration of $0.5 \times 10^{9}$ cells $/ \mathrm{ml}$ for immunization and challenge. ${ }^{14}$ The extracts and standard were dissolved in $0.5 \%$ carboxymethylcellulose (vehicle) before dosing. 


\section{Acute Toxicity}

Acute toxicity studies were undertaken as per OECD guidelines 425 . Female rats were administered a single dose of the extracts at $2000 \mathrm{mg} / \mathrm{kg} .{ }^{15}$ The following conditions were observed:

\section{Mortality/Viability/Clinical signs}

In this observation was done for first $30 \mathrm{~min}$. and at approximately 1, 2, 3 and $4 \mathrm{~h}$ after administration of the extract on test day 0 (in common with the clinical signs) and twice daily during the acclimatization period (at least once on day of sacrifice).

\section{Body weights}

They were determined on test days 0 (prior to administration) and on day 7 , day 14 and at death.

\section{Animal Models $s^{2,16,17}$}

\section{Haemagglutination Antibody Titre}

The rats were immunized by injecting $0.1 \mathrm{ml}$ of SRBCs suspension containing $0.5 \times 10^{9}$ cells intraperitoneally on day 0 . Vehicle, AL extracts and standard were given orally for 7 days. Blood samples were collected in micro-centrifuge tubes from each by retro-orbital puncture on day 7 . The blood samples were centrifuged and serum was obtained. Equal volumes of individual serum samples of each group were pooled. Twofold serial dilutions of pooled serum samples was made in 25 microliter volume of normal saline in microtitration plates and added to 25 microliter of $1 \%$ suspension of SRBCs in saline. After mixing, the plates were incubated at $37^{\circ} \mathrm{C}$ for $1 \mathrm{~h}$ and examined for haemagglutination under the microscope. Antibody levels were determined by taking the reciprocal of the highest dilution of the test serum agglutination as the antibody titre.

\section{Delayed-Type Hypersensitivity Response}

The rats were challenged by injection of $0.5 \times 10^{9}$ cells SRBCs in right hind foot pad. Foot thickness was measured after +24 and $+48 \mathrm{~h}$ of this challenge. The AL extracts were administered orally on day 0 and continued till day 7 of challenge. Right hind footpad thickness was measured with micrometer screw gauge on $7^{\text {th }}$ (prior to injection), $8^{\text {th }}$ and $9^{\text {th }}$ day of the study. Difference between prior and post injection footpad thickness was reported as DTH response.

\section{Statistical analysis}

It was done by One Way Analysis of Variance (ANOVA) followed by Dunnett test. The values were expressed as mean \pm SEM and ${ }^{\star} \mathrm{P}<0.05$, ${ }^{\star *} P<0.01,{ }^{* *} P<0.001$ and ${ }^{\star * * *} P<0.0001$ when compared with control group were considered significant.

\section{In vitro screening of the extracts using cell-lines. ${ }^{18,19}$}

All the cell cultures and media used in study comprised of human colon cancer cell Line HCT15, human breast cancer cell line MCF7 and standard drug Adriamycin (Doxorubicin) were procured and maintained at ACTREC, Kharghar, Mumbai during the studies.

The cell lines were grown in Roswell Park Memorial Institute (RPMI) 1640 medium containing $10 \%$ fetal bovine serum and $2 \mathrm{mM} \mathrm{L}$-glutamine. For present screening of extracts, cells were inoculated into 96 well microtiter plates in $100 \mu \mathrm{L}$ at plating densities, depending on the doubling time of individual cell lines. After cell inoculation, the microtiter plates were incubated at $37^{\circ} \mathrm{C}, 5 \%$ Carbon dioxide, $95 \%$ air and $100 \%$ relative humidity for $24 \mathrm{~h}$ prior to addition of experimental drugs.
The extracts were initially solubilized in dimethyl sulfoxide at $100 \mathrm{mg} / \mathrm{ml}$ and diluted to $1 \mathrm{mg} / \mathrm{ml}$ using water and stored frozen prior to use. At the time of drug addition, an aliquot of frozen concentrate $(1 \mathrm{mg} / \mathrm{ml})$ was thawed and diluted to $100,200,400$ and $800 \mu \mathrm{g} / \mathrm{ml}$ with complete medium containing test article. Aliquots of $10 \mu \mathrm{l}$ of these different drug dilutions were added to the appropriate microtiter wells already containing $90 \mu \mathrm{l}$ of medium, resulting in the required final drug concentrations i.e. $10,20,40$ and $80 \mu \mathrm{g} / \mathrm{ml}$.

After compound addition, the plates were incubated at standard conditions for $48 \mathrm{~h}$ and the assay was terminated by addition of cold TCA (trichloroacetic acid). Cells were fixed in situ by the gentle addition of $50 \mu$ of cold $30 \%(\mathrm{w} / \mathrm{v})$ TCA (final concentration, $10 \%$ TCA) and incubated for $60 \mathrm{~min}$ at $4^{\circ} \mathrm{C}$. The supernatant was discarded; the plates were washed five times with tap water and air dried. Sulforhodamine B (SRB) solution $(50 \mu \mathrm{l})$ at $0.4 \%(\mathrm{w} / \mathrm{v})$ in $1 \%$ acetic acid was added to each of the wells and the plates were incubated for $20 \mathrm{~min}$ at room temperature.

After staining, the unbound dye was recovered and the residual dye was removed by washing five times with $1 \%$ acetic acid. The plates were air dried. Bound stain was subsequently eluted with $10 \mathrm{mM}$ trizma base and the absorbance was read on a plate reader at a wavelength of $540 \mathrm{~nm}$ with $690 \mathrm{~nm}$ reference wavelength. Percent growth was calculated on a plate-by-plate basis for test wells relative to control wells. Percent growth was expressed as:

$$
\% \text { growth }=[\mathrm{Ti} / \mathrm{C}]^{\prime} 100
$$

By using the six absorbance measurements [time zero (Tz), control growth $(\mathrm{C})$, and test growth in the presence of drug at the four concentration levels (Ti)].

\section{RESULTS}

\section{Percent yield of the extracts}

Percent yield of MEAL, HMAL and AQAL was found to be 13,16 and $20 \% \mathrm{w} / \mathrm{v}$ respectively.

\section{Powder Characteristics of extracts}

The total ash value, water insoluble ash, acid insoluble ash, water extractive value, alcohol extractive value, total solid content and loss on drying were found to be $6.52,1.33,0.654,9.69$ and $12.55,3.25$ and $6.5 \% \mathrm{w} / \mathrm{v}$ respectively.

\section{Preliminary phytochemical screening}

They were found to be positive for alkaloids, carbohydrates, reducing sugars, proteins, saponins, tannins, flavonoids, phenols.

\section{Total flavonoid content in the extracts}

The total phenolic and flavonoid content of MEAL, HMAL and AEAL were found to be $22.811,18.922$ and $20.366 \mathrm{mg}$ of RU/g of extracts respectively.

\section{Analytical studies Thin Layer Chromatography (TLC)}

Rutin was found to possess Rf values of 0.85 (HMAL), 0.75 (AQAL) and 0.84 (MEAL) in comparison to the standard 0.80 whereas quercetin was found to have Rf values of 0.61 (HAML), 0.64 (AQAL) and 0.61 (MEAL) in comparison to the standard 0.64 .

\section{High Performance Thin Layer Chromatography (HPTLC)}

The extracts had shown well resolved spots on the HPTLC plate at Tracks 2, 4 and 10 in comparison to the standard at track no. 7 by comparing 
the $\mathrm{Rf}$ value at 0.81 (maximum) confirms that the spots resolved were of quercetin. The results for HMAL, MEAL and AQAL were $797 \mu \mathrm{g} / \mathrm{l}$, $71.9 \mu \mathrm{g} / \mathrm{l}$ and $839.1 \mu \mathrm{g} / \mathrm{l}$ respectively. Rutin for MEAL $(893 \mu \mathrm{g} / \mathrm{l})$ and AEAL $(2654 \mu \mathrm{g} / \mathrm{l})$ has shown well resolved spots on the HPTLC plate at Tracks 4 and 10 in comparison to the standard at track no. 5 and 10. (Table 1 and Figure 2).

\section{FTIR SPECTROSCOPY}

The standard quercetin showed major peaks at 3275.13, 2353.16, $1666.50,1606.70,1519.91,1446.61,1091.71,1014.56,819.75,721.38$ and 673.16 which confirmed the presence of alcohols, phenols, alkenes, aromatic rings, amides, carboxylic acids, ketones and alkyl halides respectively. In addition, standard rutin relieved major peaks at 3421.72, $3331.07,2920.23,2858.51,1658.78,1598.99,1502.55,1452.40,1359.82$, $1203.58,1132.21,1060.85,808.17,630.72$ and 594.08 which confirmed the presence of alcohols, phenols, alkanes, alkenes, ketones, aromatic rings, anhydrides, amides, aliphatic amines and alkyl halides respectively as shown in Figure 3A and 3B.

MEAL shows major peaks at 2922.16, 1670.35, 1598.99, 1452.40, 1105.21, 744.52, 682.80 which confirms the presence of alcohols, phenols, alkanes, alkenes, carboxylic acids, amines, aromatic rings, anhydrides, aliphatic amines, alkyl halides respectively. HMAL shows major peaks at 3356.14, 2353.16, 1612.49, 1452.40, 1033.85, 717.52 and 2918.3 which confirm the presence of alcohols, phenols, aromatic rings, alkenes, alkanes, ketones, amines, anhydrides, aliphatic amines and alkyl halides respectively. AQAL shows major peaks at 3315.63, 2920.23, $1591.27,1404.18,1103.28,1043.49,713.66$ and 644.22 which confirms the presence of alcohols, phenols, alkanes, aromatic rings, ketones, alkenes, amines, aliphatic amines and alkyl halides respectively as shown in Figure 4A,B,C.

\section{Animal studies \\ Acute Toxicity Mortality/Viability/Clinical signs}

The extracts were reported therapeutically safe up to $2000 \mathrm{mg} / \mathrm{kg}$ b.w and rats appeared normal thought the studies.

\section{Body weights}

All surviving animals had gained body weight by day 14 as compared to day 0 .

\section{Animal Models Haemagglutination Antibody Titre}

HMAL (597.33 \pm 85.35$)$ and AQAL (554.66 \pm 102.78$)$ extracts at $200 \mathrm{mg} / \mathrm{kg}$ showed significant activity and MEAL (426.66 \pm 53.98$)$ as comparable to the standard. No activity was reported at $100 \mathrm{mg} / \mathrm{kg}$. (Figure 5).

\section{Delayed-Type Hypersensitivity (DTH) response}

The MEAL $(0.23 \pm 0.01)$, HMAL $(0.25 \pm 0.02,0.21 \pm 0.01)$ extracts showed significant activity at both the dose levels. AQAL $(0.225 \pm 0.01)$ showed significant activity at $200 \mathrm{mg} / \mathrm{kg}$. Thus, Figure 5 depicts good immunosuppressant potentiality.

\section{In vitro screening of the extract using cell-lines}

In-vitro screening of extracts were found to be ineffective on selected cell lines at different concentrations studied as compared to standard drug Adriamycin as shown in Figure 6.

\section{DISCUSSION}

Identification of phytoconstituents has gained rapid attention in recent decades due to the progress of chromatographic techniques. TLC is

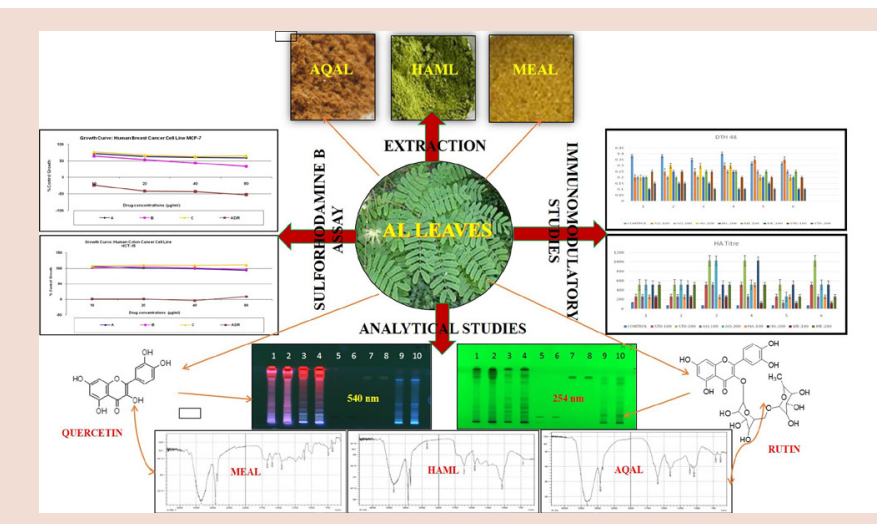

Figure 1: Graphical Abstract.

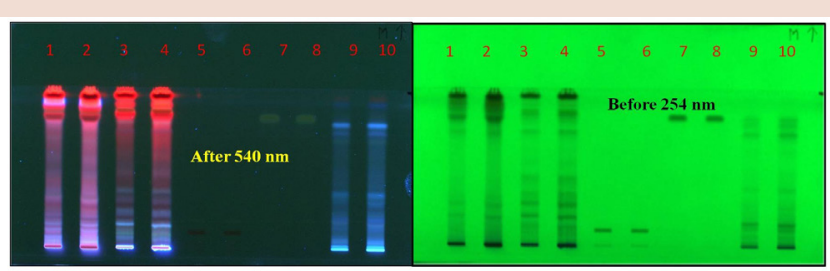

Tracks 1 and 2 - HMAL, Tracks 3 and 4 -MEAL, Tracks 5 and 6 -Rutin, Tracks 7 and 8-Quercetin, Tracks 9 and $10-A Q A L$.

Figure 2: HPTLC Images.

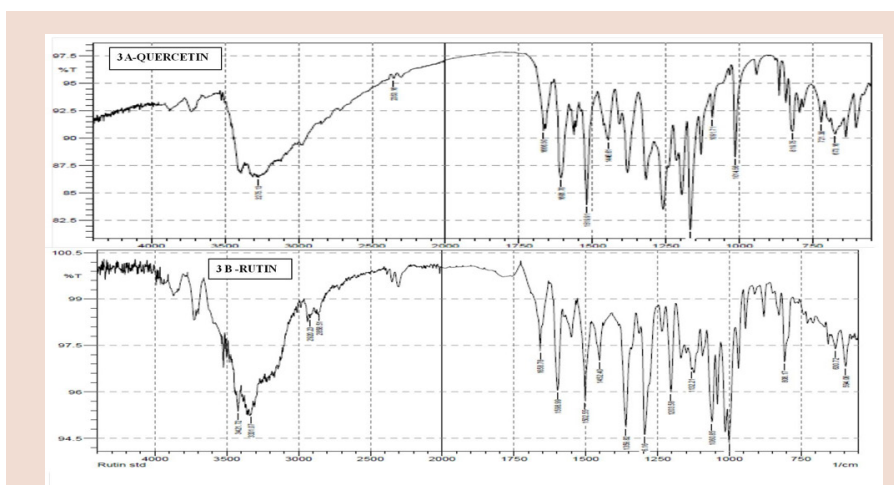

Figure 3 A and B: FTIR of standard quercetin and rutin.

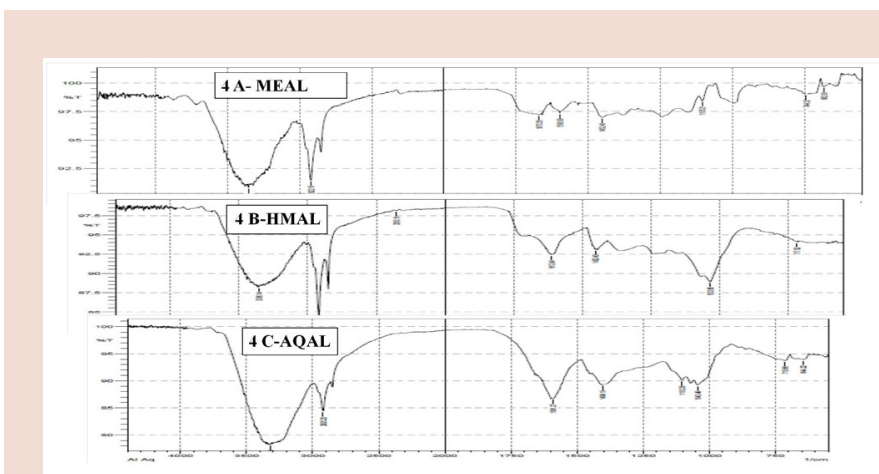

Figure 4 A B C: FTIR of MEAL, HMAL and AQAL respectively. 


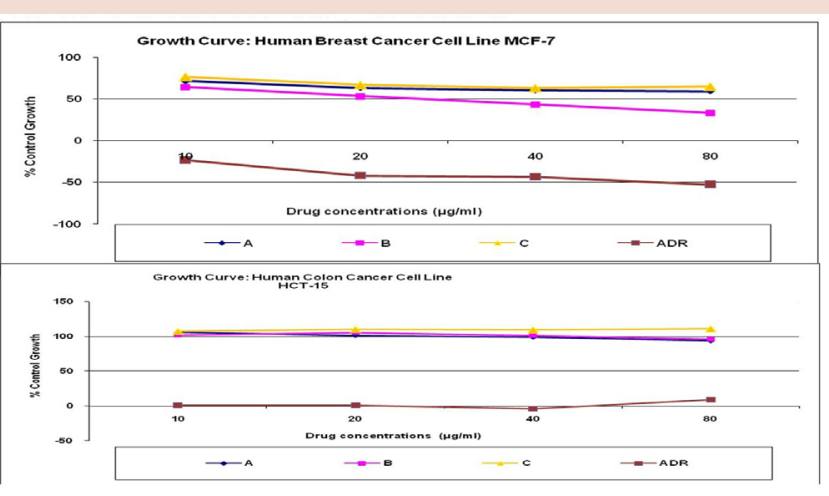

Figure 5: In vitro screening of extracts.

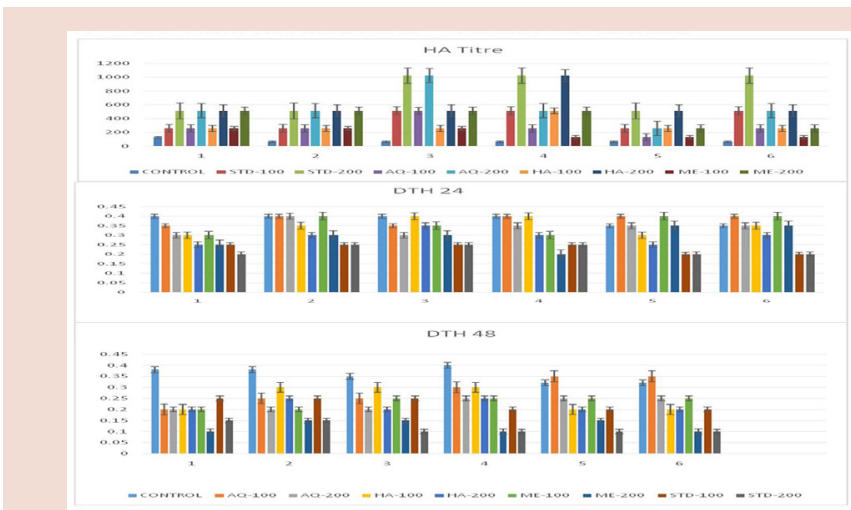

Figure 6: Immunomodulatory studies on extracts.

one of the cheapest and versatile analytical methods preferred for these studies. HPTLC technique marks its importance in this field due to its precision, accuracy and advantage of linearity and recovery of sample (99.24\%). Even $\mu \mathrm{g}$ amounts of the material separation can be achieved by this technique. ${ }^{20,21}$ The IR spectrum shows spectral bands or peaks due to the presence of individual bonds or functional groups present in extracts. Its major advantage is as a fingerprinting device for comparing a natural component as well as synthetic sample. ${ }^{20}$ In current research studies, MEAL, HMAL (rutin absent in HPTLC) and AQAL extracts showed the presence of flavonols compounds viz; rutin and quercetin confirmed based on maximum $\mathrm{Rf}$ value in comparsion with the standard. In current studies, the researchers have tried to state the presence of rutin and quercetin in extracts based on its comparsion with the standard as depicted in FTIR chromatograms.

White blood corpuscles encompasses of neutrophils, basophiles and eosinophiles responsible for macrophage activity whereas lymphocytes such as B cells (Bone marrow), T-cells (Thymus) and monocyctes participate in enhancing the immune system responses with the help of natural killer cells. ${ }^{22,23}$ In current studies, it is not possible to perform investigation of studying such reactions in human population due to stringent ethical considerations. Hence, the alternative was using rats which are found to posses Ox49 antigen equivalent to functionally important protein designated as $\mathrm{CD}_{2}$ in $\mathrm{SRBC}$ receptors to which these antigens bind in an antigen specific mechanism, catalyze cell activation and finally on incubation with SRBCs lead to rosettes formation which is an underlying concept of immunomodulatory studies. ${ }^{14,2}$
Receptors located on B-cells stimulate antigen specific antibodies. In the host, short lived plasma cells recognize circulating soluble antigens under the chemical influence of T-cells and start to secrete antibody molecules which are a product of B-lymphocytes and plasma cells. Long lived memory cells respond to the same antigen if encountered next time by keeping them post in their memory. The extracts (Figure 6) indicated high values suggesting enhanced responsiveness of $\mathrm{T}$ and $\mathrm{B}$ lymphocytes playing a vital role in uplifment of humoral mediated immunity. ${ }^{24,25}$

$\mathrm{T}$ specific-cell receptors have presence of antigen-specific molecules which serve as molecular markers on their surface matching to antibodies. They recognize these antigens when they are presented by combination with proteins of Major Histocompatibility Complex (MHC). Release of histamine helps T-lymphocytes to battle towards infectious organisms, foreign grafts, tumors and variety of hypersensitivity reactions. ${ }^{1,24,25}$ The extracts showed decrease in the paw volume over a period of $48 \mathrm{~h}$ suggesting immunosuppresant potential.

SRB assay has advantage over MTT because of rapidity, senstivity, reliability and inexpensive methodology for analyzing the cellular protein. It provides end point that is stable, visible to the naked eyes and non destructive. It strongly fluoresces with laser excitation at $448 \mathrm{~nm}$ and interpreted quantitatively at the single cell level by the principle of static fluorescence cytometry. ${ }^{26}$

Cancer is one of the major concerns in the world. ${ }^{27}$ Colon and breast cancer are most prevalent. It is estimated that about $90 \%$ of the colon cancer occurs after the age of 50 in American population. Moreover, breast cancer which occurs at a high frequency is the leading cause of death in women in majority of developed nations. At present, chemotherapy and radiotherapy are the main conventional methods being used in the treatment of cancer. ${ }^{28}$

In 1970, the utility of MCF-7 cell line as an investigative and novel tool led to its adoption in research laboratories across the globe since it appears to mirror the heterogeneity of tumour cells in vivo. It is popular due to its exquisite hormone senstivity expressed through oestrogen receptor. It is regarded as one of the excellent in-vitro cell line for correlating and studying mechanisms of tumour response to endocrine therapy and also other complex mechanisms which are involved in binding biological actions of these hormones. Colorectal cancer is known to be one of the leading causes of death in the United Nations. HCT-15 cells are thought to possess mutant p53 which is often expressed in variety of human tumours and contribute to malignant process. ${ }^{29}$ The extracts were found to be unsatisfactory in comparsion to the standard at the selected concentrations.

Thus, in a nutshell we would like to conclude our studies by putting forth a remark that AL leaves have good immunomodulatory potential due to the presence of rutin and quercetin but are found to be ineffective on the selected cell lines at the mentioned concentrations in the studies. Further, detailed studies on the characterization and identification of various extracts could be explored in order to establish its probable role in prevention of immune system related disorders.

\section{ACKNOWLEDGEMENT}

We would like to acknowledge the college management and Principal, Dr. Supriya Shidhaye, VESCOP who provided us all the facilities to screen the plant for immunomodulatory activity with the aid of contingency grant, Anchrom Research Laboratories Pvt. Ltd. for HPTLC studies and Advanced Centre for Treatment Research and Education in Cancer for anticancer studies.

\section{CONFLICT OF INTEREST}

We have no conflict of interest. 


\section{REFERENCES}

1. Ananthanaryan R, Paniker JCK. Antigens. In Text of Microbiology Part II, $6^{\text {th }}$ Ed, Orient Longman Limited Publishing House, Hyderabad. 2000;67-148.

2. Doshi GM, Une HD. Screening of Polyalthia longifolia Leaves as Potential Immunomodulatory Target. Int J Pharmacol. 2015;11(2):106-13.

3. Pelczar MJ. Basic and Theoretical Aspects of the Immune Response. In Microbiology $5^{\text {th }}$ Ed, Tata McGraw Hill Publishing Company Limited, New Delhi. 1993;718-9.

4. Gupta SK. Anticancer agents for Immune Based Disorders Antinflammatory agents and ocular inflammation. In Drug screening methods (Preclinical evaluation of new drugs), 2 ${ }^{\text {nd }}$ Ed, Jaypee Brothers Medical Publishers (P) Ltd, India. 2009;p.246-57.

5. Thatte UM, Dahanukar, SA. Ayurveda and contemporary scientific thought. Trends Pharmacol Sci. 1986;7:247-51.

6. Doshi GM, Chaskar PR, Zine SP, Une HD. Solicitation of HPLC and HPTLCTechniques for Determination of Rutin from Polyalthia longifolia Thwaites. Pharmacogn Res. 2014;6(3):234-9.

7. Doshi GM, Shanbhag PP, Une HD. Rasayans and Non-rasayans: Future Immunodrug Targets. Pharmacog Rev. 2013;14(7):92-6.

8. Chaudhary M, Kumar A, Sharma, Kumar R, Chauhan B, Kovidendra K, Vipin. Comparative immunomodulatory activity of leaves and bark of Albizia Lebbeck. J Chem Pharm Res. 2011;3(11): 675-84.

9. Kumar D, Arya V, Kaur R, Bhat AZ, Gupta VK, Kumar V. A review of Immunomodulators in the Indian Traditional Health care system. Int J Res Dev Pharm Life Sci. 2012:5-7.

10. Kokate CK. Practical Pharmacognosy. $2^{\text {nd }}$ Ed, Vallabh Prakashan New Delhi, India. 1989;111-4.

11. Khandelwal KR. Practical Pharmacognosy-Techniques and Experiments. $10^{\text {th }}$ Ed, Nirali Prakashan Pune. 2003;149-56.

12. Stankovic MS. Total phenolic content, flavonoid concentration and antioxidant activity of Marrubium peregrinum L. extracts. Kragujevac J Sci. 2011;33:63-72.

13. Alali F, Tawaha K, El-Elimat T, Syouf M, El-Fayad M, Abulaila K, Nielsen SJ, Wheaton WD, Falkinham III JO, Oberlies NH. Antioxidant activity and total phenolic content of aqueous and methanolic extracts of Jordanian plants: an ICBG project. Nat Prod Res. 2007;21(12):1121-31.

14. Bader JM. Identification of T Iymphocyctes In: Glase J C (Eds.) Tested Studies for Laboratory Teaching, Vol 18 Kendall/Hunt Publishing Company, USA. 1997, p. 113-23.

15. OECD Guideline for Testing of Chemicals: Acute Oral Toxicity - Acute Toxic Class Method: Adopted: $17^{\text {th }}$ December. $2001 ; 1-14$
16. Shukla S. Mehta A. John J, Mehta P, Vyas SP. Immunomodulatory activities of ethanolic extract of Caesalpinia bonducella seeds. J Ethnopharmaco I. 2009;125:252-6.

17. Vogel GH. In: Drug Discovery and Evaluation, Pharmacological Assays. Chapter I: Methods for testing immunological factors, $2^{\text {nd }} \mathrm{Ed}, 2002$, p.788-820.

18. Vanicha $V$, Kanyawim K. Sulforhodamine B colorimetric assay for cytotoxicity screening. Nat Prot. 2006;1(3):1112-6.

19. Doshi GM, Une HD. In vitro cytotoxicity studies on Carissa congesta, Polyalthia longifolia, and Benincasa hispida extracts by Sulforhodamine B assay method. Int J Green Pharm. 2015;9(3):157-61.

20. Harborne JB. Phytochemical methods: A guide to Modern Techniques of Plant Analysis. $3^{\text {rd }}$ Ed, Springer (India) Private limited Publication House, First Indian Reprint, New Delhi, India. 2005;11-22.

21. Nagore DH, Patil PS, Kuber VK. Comparison between High Performance Liquid Chromatography \& High Performance Thin Layer Chromatography for determination of Diosgenin from the fenugreek seeds. Int J Green Pharmacy. 2012; 6(4):315-20.

22. Barar FSK. Immune System, Immunosuppressants and Immunostimulants. In: Essentials of Pharmacotherapeutics. $5^{\text {th }}$ Ed, S Chand and Company Limited, New Delhi. 2009;489-92.

23. Goodman and Gilman. Chapters: Pharmacotherapy of Asthma by Bradley JU and Immunodulators - Immunosuppressants, Tolerogens and Immunostimulants by Alan M Krensky, Flavio Vincek and William M Bennet. In: The Pharmacological Basis of Therapeutics. Edited by Laurence L. Bruton and John S Lozo, Keith L Parker, $11^{\text {th }}$ Ed. Published by Mc- Graw Hill Medical Publishing House. 2005;717-36 \& 1405-32

24. Miller LE. Manual of Laboratory Immunology. In: Ludke HR, Peacock JE, Toma RH (Eds.), Lea and Febiger London. 199;1-18.

25. Benacerraf B. A hypothesis to relate the specificity of $T$ lymphocytes and the activity of I region specific Ir genes in macrophages and borrower lymphocytes. J Immun. 1978;120(6):1809-32.

26. Keepers PY, Piazo PE, Peters JG, Otte JVA, Winogard B, Pinnedo HM. Comparison of the Sulforhodamine B protein and Tetrazolium (MTT) Assays for in vitro chemosenstivity testing. Eur J Cancer. 1991;27(7):897-900.

27. Parasramka MA, Gupta SV. Synergistic effect of garcinol and curcumin on antiproliferative and apoptic activity in pancreatic cancer cells. J Oncol. 2012:709-39.

28. Nair PP, Turjman N, Kessie G, Calkins B, Goodman GT, Davidovitz H, Nimmagadda G. Diet, nutrition intake, and metabolism in populations at high and low risk for colon cancer. Am J Clin Nutr. 1984;40(4):927-30.

29. Nautiyal J, Kanwar SS, Yu Y, Majumdar APN. Combination of dasatinib and curcumin eliminates chemo-resistnat colon cancer cells. J Mol Signaling. $2011 ; 6: 1-11$. 
PICTORIAL ABSTRACT

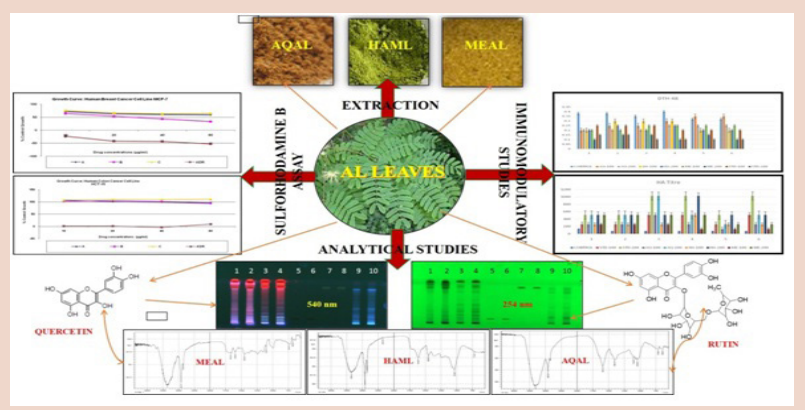

\section{SUMMARY}

- Albiza lebbeck leaves have been studied at two dose levels by immunomodulatory models (HA,DTH) and in vitro cell lines (HCT 15, MCF 7) in correlation to analytical studies (FTIR,HPTLC).

- Significant immunomodulatory effect was noticed at $200 \mathrm{mg} / \mathrm{kg}$ with $\mathrm{HA}$ and DTH models.

- Unsatisfactory results were obtained for cell lines. Rutin and quercetin were identified in the extracts by FTIR and HPTLC. The present paper suggests that extracts has immunomodulatory potential.

\section{ABBREVIATIONS USED}

MEAL: Methanolic extract of Albizia lebbeck; HMAL: Hydromethanolic extract of Albizia lebbeck; AQAL: Aqueous extract of Albizia lebbeck; TLC: Thin Layer Chromatography; HPTLC: High Performance Thin Layer Chromatography; FTIR: Fourier Transform Infrared (FTIR) Spectroscopy; HA: Haemagglutination Antibody Titre; DTH: Delayed-Type Hypersensitivity Response

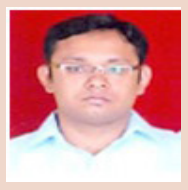

\section{ABOUT AUTHORS}

Dr. Gaurav M. Doshi: Presently working as Assistant Professor, Department of Pharmacology, Vivekanand Education Society's College of Pharmacy, Chembur (East), Mumbai- 400074. He has 36 journal papers; 85 citations to his credit. He has completed Ph.D from Department of Pharmaceutical Sciences, Pacific Academy of Higher Education and Research University, Udaipur, Rajasthan, India in 2016.

Ms. Manjushree Kundalik Pawar: Presently M.Pharm research Scholar at Vivekanand Education Society's College of Pharmacy, Chembur (East), Mumbai- 400074.

Ms. Kajal Haribhai Chavda: Presently M.Pharm research Scholar at Vivekanand Education Society's College of Pharmacy, Chembur (East), Mumbai- 400074. 